\title{
Exposure Yes No Indicator
}

National Cancer Institute

\section{Source}

National Cancer Institute. Exposure Yes No Indicator. NCI Thesaurus. Code C87885.

An indication of whether an exposure occurrence has taken place. 